\title{
Under One Roof: The University of New Hampshire's New Library
}

$\mathrm{N}^{\mathrm{E}}$

EW Hampshire's Hamilton Smith LIBRARY, a typical Carnegie structure, was erected in 1907, with funds provided by the New Hampshire College of Agriculture and the Mechanic Arts (as it was then called), the Carnegie Corporation, and a bequest from Hamilton Smith, internationally known engineer who had made Durham his home. (In 1906 the Town of Durham and the college had agreed to combine library resources, "in perpetuity." Durham turned over its library to the college, and contracted to pay at least $\$ 25.00$ a year thereafter for the purchase of books. The college contracted to assume all other expenses.) The library grew wings in 1937/38, thus trebling both space and administrative problems. In 1940 a small stack area was added.

Plans for further expansion had been in the air since 1940, but remodeling began to be seriously discussed when, in $1950,10,000$ books were crowded out of the Library into storage space above a garage across the campus. Eventually it became clear that no remodeling would ever be successful. By 1952 thinking had turned toward a new building.

It was generally conceded that Hamilton Smith occupied the ideal site for a library on campus. The new site, then, should be in the same locality. The final choice was admirable - it is close to the administrative offices and to the liberal arts buildings; equidistant from men's and women's dormitories; and near to the Memorial Union. It is visible from

Miss Brackett is Librarian, University of New Hampshire. the main street - a fact of importance in the eyes of the trustees.

Standing on a slope toward a ravine (to be landscaped as one of the campus beauty spots), it makes possible four ground-level entrances: main floor, delivery door, and two others not commonly used. The university library has had open stacks for the last seventeen years, and plans to keep them so. It may at any time, however, need to check books at the door. Hence the main entrance, next to the loan desk, is the only one in general public use. The delivery door and loading platform, two flights down, are on the north side of the building. The lowest floor has a door toward the ravine -a fire door only. And one level below the main floor, opening onto a covered walk, are two glass doors, one from a large smoking study, one from an exhibit lounge. These too are ordinarily fire doors only.

Flexibility seemed of the utmost importance when the needs of the university library were under consideration. How can the educational requirements even ten years hence be foretold in today's world? Consequently, a modular building with supporting columns and as few permanent walls as possible-and these not structural-was decided upon. The size of the module, the architect's decision, was set at $18^{\prime} 4^{\prime \prime} \times 24^{\prime} 4^{\prime \prime}$. The columns carry electrical wires and ventilating ducts, which are adequate in size for air conditioning when the time comes to install it. Outlets are installed on each column. The stairwells, elevator well, and toilet walls are permanent, and should be found as conveniently located 
in the future as they are at present. For in time the building will be enlarged, first by adding a story and a half (foundations are planned to sustain the added weight), and second by building an additional unit to the south.

The librarian had no desire to concern herself about the exterior details of the building. Since brick was the prevailing building material on campus, it would be used. Two concerns only were felt: that the approach present no stairs to climb, and that money be spent on practical needs rather than on exterior adornment. (The future addition to the building was the final factor in deciding the type of roof.) The same attitude was held in respect to space within the building. Every inch must be utilized, and none wasted on lofty ceilings and impressive corridors. On this note of practicality ceiling heights were finally established-the main floor ceiling $9^{\prime} 311^{\prime \prime}$, the others $8^{\prime} 31 / 2 "$.

I can think of no better training for planning a new building than working in a completely inadequate one. Equally valuable was a six-month sabbatical trip across the country looking at buildings and talking with librarians generous with their time and the results of their own experience. I should like here to record my gratitude to them all. At any rate, the pooled ability of a competent staff, working with an interested faculty library committee, resulted in a layout for the new building that is proving highly satisfactory. The staff work without waste motion and time, the students can study as uninterruptedly as they desire, those seeking books are finding their way around with increasing ease.

In the final grading two low steps were necessary to reach the wide concrete slab approach to the ten-foot flagstone portico. But those steps are easy, and to one side a ramp provides access for wheel chairs. The latter were kept in mind also when doorways throughout the building were planned. A book depository makes possible the return of books when the library is closed.

The visitor enters first a lobby with two sets of glass doors and exhibit cases on both walls, above handsome gumwood paneling. Once past the inner doors, he is standing beside a large, $\mathrm{L}$-shaped loan desk, smoothly paneled of hard rock maple, linoleum-topped, with slots for the return of books and depressible-top trucks to receive them. A glance to the left reveals books-a browsing alcove and next to it, a newspaper reading room; through glass walls, a children's room. Ahead is a reading room, also glassed, and beyond are the reference books. The glass walls, a handsome open stairwell, the prevalence of books, all are friendly and welcoming.

Reference books, current issues of periodicals on their slanting shelveswith the rest of the current volumes on straight shelves below-and bibliographical material are all in close proximity, for the convenience of the users. A small built-in reference desk, accessible from both loan desk and catalog, encourages the student to ask for help when he needs it. This arrangement is proving gratifyingly successful.

A suggestion of a liberal arts faculty committee was followed when six typing carrells were placed in the reference area. Typists desiring to use them must furnish their own machines. Their usefulness for the intended purpose may be minimized because of the Contoura service now offered by the library. But students prize them to study in!

Behind the loan desk, in a recessed module, are stacks for reserve books, and a small $\left(8^{\prime} \times 18^{\prime}\right)$ office for the loan librarians, with walls of steel and glass. Here conversations can be carried on unheard by others, and the librarians can supervise the desk while tackling their endless paper work.

Looking across the desk and past the 
office, the visitor can see the length of the building and the technical processes staff preparing books for the reader to use. The technical processes area extends through seven modules (approximately 2,930 square feet), and has on one side, windows and desks, on the other, book shelving. Down the center are catalog cases for shelf lists and other tools. There are no dividing walls. The work is so planned that a truck of new books, opened in the mail room two floors down, goes up in the elevator directly to the order department. Checked in at that point, the books go to the catalogers, the processers, the loan desk. If they are not put on exhibit for a week, the electric booklift at the loan desk carries them, still on trucks, to their respective floors. The staff feels that the visibility of this essential part of the life of a library is in itself educational. And the productionline arrangement is essentially sound.

There is no reserve book room in the building. For better service, and to eliminate one extra service point, reserve books are handled at the loan desk, and can be taken for use anywhere in the building. On the main floor is a reading room, $40^{\prime} \times 55^{\prime}$, where students may study if they do not wish to smoke. The west wall is made up of windows looking out over the ravine with its handsome old trees; the east wall, toward the loan desk, has glass windows. Those students who wish to smoke can go to one of three smoking studies, one on each open floor other than the main floor. For others, individual study tables are placed around all walls, and islands of larger tables are found in the stacks. The plan is to bring together students and books. Students cannot reach any study area without passing shelves of books.

The largest of the three smoking studies, approximately $50^{\prime} \times 24^{\prime}$, is one flight down from the main floor, with its entrance directly in line with the main stairway. Glass doors open onto the covered walk and what will in time be a pleasantly landscaped court. The room is so planned that it can be used without access to the rest of the library. Ordinarily, however, the outside doors are fire doors only.

Next door is the exhibit lounge, approximately $36^{\prime} \times 24^{\prime}$, also with glass doors opening onto the court. When desired (as for a tea or a special meeting) these doors can be used; otherwise they too are considered to be fire doors. The exhibit lounge leads onto an exhibit area about $64^{\prime} \times 24^{\prime}$. In this space, or part of it, exhibits arranged by the Department of the Arts are shown; if the exhibits require more space, they can be extended into the lounge, which is made up of two modules. Three accordion walls may be folded back to their columns, or extended to make the lounge area into two conference rooms, cut off completely from the exhibits. A new arts building, now under construction, will when completed provide space for the campus exhibits, and thereafter other uses will be found for this space in the library.

Here it might be appropriate to mention the loan picture collection developed for the students. Framed pictures, mostly reproductions, but with a few originals, are lent a semester at a time, to hang in the students' quarters. Heretofore it had been necessary to reserve the exhibition room for three days at the beginning of each semester, and to find time to hang the pictures. Staff time so spent seemed wasteful. Today the library has a number of especially designed screens. On metal frames, with strong meshed wire stretched on the frames, and triangular bases wide enough to make them steady, they are mounted on rollers and can easily be moved. Their length and height were determined by the length of the elevator and the height of its door. When not in use, they nest 
and take up little space. As pictures are returned, they are hung directly on both sides of the frames, and can be viewed on the frames by the shopping student. An exhibit preparation room off which the elevator opens is large enough to store the frames when not in use.

On the same floor (Floor A) are four micro-machine alcoves and nine listening rooms, so grouped as to be controlled by the same attendant who oversees the exhibits. Glass walls on both ends of the exhibit area serve two purposes-they invite the passerby and they protect the exhibits. Two of the listening rooms are large enough for classes, seven are for individual listeners. When the four micro-machines now in use become inadequate for the library's needs, additional machines can be plugged into outlets near by, already put in for the purpose.

Listening rooms and micro-machines presuppose storage space for records, film, cards. A room, about $18^{\prime} \times 15^{\prime}$, provides that space. Close at hand too is a small coat room for student assistants.

It will be seen that the public services are grouped on two floors-all lending of materials, reference and bibliographical work on the main floor; exhibits, listening rooms, micro-reading on Floor A. Floor $\mathrm{A}$ has in addition stacks and study areas, and an archives room, three modules in size. Here too are located the staff quarters-staff room, locker room, toilets, kitchenette-with a Dwyer unit given by a generous alumnus. The kitchenette is handy also to the exhibit lounge.

The top floor, one-half the size of the floors below, contains stacks for noncurrent periodicals and at present the United States serial set, a conference room, and study areas-including the smoking study.

Floor B's open area is for stacks and study, and one conference room. Behind the scenes, the delivery door opens into the mail room, where mail, express, and freight are delivered and opened, where packages are wrapped, and books packed for the bindery. On this level are various service activities - the serials room, where all serials are checked in; the photography room, for Contoura and microfilm copying; the janitors' quarters and the supply closet.

Floor C, closed to the public, is stacked in seventeen of its twenty-six modules. The New Hampshire collection, all "closed" items, and uncataloged gift books are housed here. Three modules provide storage space for bulky objects. Five modules are taken up with mechanical equipment.

Special attention was paid to the planning of drinking fountains, electric clocks, public toilets, and janitors' closets. All are adequate, strategically placed, and indispensable. The librarian had hoped originally that a master switch could be installed which would make it possible to flick off the lights as a closing signal. Expense eliminated the idea. When the building is being closed, lights are turned off at eight panels, two on each floor. (The lights on Floor $\mathrm{C}$ are turned on only as needed, by wall switches.) A chimes system announces the closing hour. An adequate intercommunicating system was considered to be a requisite. Expense again loomed as a stumbling block. But an inadequate call system plus first-rate intercommunication by telephone seems to be working satisfactorily.

Two policy decisions that influenced planning should be mentioned. One concerns the elevator. It finally seemed desirable to consider it a freight, not a passenger, elevator, and so all doors to it open into closed areas. With the main entrance midway of the building, the stairs to be covered by library users are at a minimum. The other question revolved about readers' coats. Should there be a coat room? Experience has shown 
that a coat room with no attendant is not a safe place. An attendant would add expense to the payroll, so coat-racks are spread about through the various levels. They seem to answer their purpose adequately, although admittedly they do not add to the beauty of a room.

The one unsatisfactorily solved problem in the layout of the building was the location of offices for librarian and assistant librarian. To reach them, it is necessary to go first through the reading room on the main floor. A screen has been ordered which will make the passageway inconspicuous, but even without it the location seems less undesirable than had been expected. The rooms themselves are attractive, and the librarian has undoubtedly the pleasantest possible office, a south and west exposure with a happy view in both directions. Next to her office is the secretary's, and beyond that, the assistant librarian's.

In selecting furnishings and color, an effort was made to be both uninstitutional and practical. It was necessary to use all the old equipment possible, including all freestanding stacks and as many metal shelves as could be converted to use. All new stacks too are freestanding, with colors (yellow, tan, red, blue) different on different levels. Outside walls are cinder block, painted; columns, painted plaster; interior walls, blue steel. Paints were necessarily chosen to harmonize with the blue of the steel. Much red is in evidence, along with white and yellow and gray.

Wooden furniture is all light in tone. New catalogs and catalog tables, especially designed maple Library of Congress shelving, with pull-out shelves for ease in reference, 265 new individual study tables, and the old twelve-foot standbys refinished to a beautiful sheen by workers at the State Prison--all help set the tone of the new building. In order to seat a maximum of readers about a third of the chairs provided are comfortable occasional chairs, without tables. Herman Miller molded plastic chairs were chosen, and a variety of upholstered (washable fabric) arm chairs. The proportion of occasional chairs to table chairs was decided after a survey in Hamilton Smith of the number of students who actually needed tables.

One problem-west windows-was happily solved with curtains of diffusion cloth made by Edwin Raphael Company. They can be drawn at will, and comfortably control the sunlight without shutting out air or cutting off the view.

Faculty members wish that the library were large enough to provide them with studies. Ordered, but not yet received, are faculty lockers, specially designed, so that those who wish may have a space in which to store the books on which they are working. The theory is that books so stored will be charged at the loan desk, if they belong to the library. In any case, the books inside the lockers will not be invisible; and the librarian will have a master key.

I am happy to report that the library is today being criticised only because it is not open both all day and all night.

\section{Building Data}

Name: The University Library.

Architects: Tracy and Hildreth, Nashua, New Hampshire.

Type of construction: Structural steel; exterior walls, bricks; interior, cinder block.

Exterior decoration: Granite; extruded aluminum on Albarene, by sculptor Bertram A. Kilgore, Woburn, Massachusetts.

Size: 89,146 square feet.

Cost of building: $\$ 1,109,000$.

Lighting: Largely fluorescent.

Heating: Forced-circulation hot water.

Ventilation: Forced air.

Book capacity: 375,000.

Seating capacity in study areas: 715 .

(Continued on page 211) 
smaller rooms have for the most part been retained, but have been converted to new uses: a shipping room; a microfilm and microcard reading room; a microfilming laboratory, complete with dark-room; a conference room; a library science classroom, with adjoining office; a staff room; and a North Louisiana archives room. The second floor rooms which previously served as the periodical reading room and the browsing room have been combined into a single, large technical processes room; a private office for the circulation staff has been provided at the side of the charging desk; the former reference room now houses the card catalog, the office of the head of reader services, and a recreational reading area adjoining the humanities division. The third floor, comprising four seminar rooms and a large classroom, remains unchanged. In addition to the rooms and areas already enumerated, there are several large storage closets on each floor, quarters for the janitor, and a machinery room.

Two of the most important features of the building are the lighting and the airconditioning systems. The fluorescent light fixtures, which are recessed into the ceiling, are placed end-to-end in strips running across the entire width of the building, the strips being three feet apart on centers; the illumination provided is evenly distributed and shadowless, with an intensity of approximately eighty foot-candles at table top level. The entire first and second floors have been air conditioned. A hydraulic elevator has been installed also.

The building is of modified Tudor architecture, with exterior walls of red brick in blended shades. The interior walls are painted in pastel hues of blue and green; the stair-wells and first floor corridors are enlivened with touches of orange. The concrete floors are covered with asphalt tile, which is so designed as to resemble cork. The old portion of the building and the new have been so completely integrated that it is now difficult to distinguish between the two.

The library furniture and the filing cabinets were supplied by Remington Rand, the free-standing steel stacks and the carrel desks by Estey, and the office furniture by Security.

William H. Jesse, director of libraries, University of Tennessee, assisted with the preliminary plans. Edmon Low, librarian, Oklahoma State University, served as official library consultant throughout the planning and construction stages. E. P. Dobson, of Houston, Texas, was the architect.

\section{Under One Roof}

(Continued from page 201)

Equipment contractors

Stacks: Estey Metal Products.

Library furniture: Loan and reference desks, catalogs, tables.

LC shelving: Twombly Associates (Myrtle Desk Company).

Lounge and occasional chairs: International Hotel Supply Company and New England Contract Furnishings, both Boston, Massachusetts.

Steel furniture: All-Steel Equipment.

Curtains: Edwin Raphael Company; Margeson's, Portsmouth, New Hampshire.

Picture racks: Nevlen Company, Wakefield, Massachusetts. 